conifer trees, in particular Sitka and Norway spruce, which account for a large part of British woodlands. It is endemic in Northern Europe where forestry management techniques have already been adapted to its presence. The last serious outbreak was in Holland in 1955 but after a four-year programme the beetle was eradicated.

The female great spruce bark beetle attacks spruce 20-25 years old when the bark is thick enough for her to eat out a small protective chamber where she can lay her eggs. Trees which are suffering stress are particularly vulnerable. The $100-300$ eggs, laid in two broods, hatch out and the larvae feed on the edge of the chamber before emerging as adults. In serious cases grubs eat out grooves, causing ring bark.

To contain the attacks, affected trees have to be felled and stripped of their bark which is burned on site or sprayed with insecticide. The Forestry Commission has the power to ensure that owners of woodland, both private and public, take action and destroy infested trees.

It is likely that the beetle arrived in Britain in imported timber that was not properly stripped but, because the life cycle of the beetle varies from one to four years, it is impossible to know how long it has been in Britain. What seems certain is that now Dendroctonus micans has crossed the Channel it looks like being a pest we will have to learn to live with.

Jane Wynn

\section{East German scientists}

\section{Too many now}

Science planners in the German Democratic Republic (GDR) have failed to come up with a coherent policy for the division of labour in science, according to leading East German sociologist, Professor Manfred Loetsch. Speaking on Berlin radio, Professor Loetsch claimed that this bad planning was a major cause of the disparity between spending on science and technology and the rise in productivity in the GDR.

Part of the problem, Professor Loetsch suggested, lies in the pay structure of East German science. In general the GDR has a pay policy based on payment by results. But this principle does not apply in science, where there is a fixed pay scale according to the grade of post.

Incentives, however, are not the only requirement for increased scientific productivity. Science in the GDR, said Professor Loetsch, is greatly hampered by the lack of "intermediate personnel". Higher education was greatly expanded during the last decade, but this expansion has not been matched by a parallel growth in the training of technicians. Indeed, the science planners seem to have neglected the need for such auxiliaries, so that whereas the international average for technical research gives six auxiliaries to one scientist, in the GDR the ratio is 0.8 to one. Frequently, Professor Loetsch complained,

\title{
Embarrassing admissions cause trouble
}

Mathematicians and human-rights activists in the West are preparing a petition to appeal for the release of a Soviet colleague, Valerii Senderov, formerly a teacher in one of the Soviet Union's schools for mathematically gifted children. Senderov was arrested in June and is now in pre-trial detention. He will probably be charged under article 70 (anti-Soviet agitation) or article 190/1 (slandering the state).

From the official Soviet point of view, Senderov is a double offender. In 1978 he was a founder member of SMOT, the unauthorized "Inter-professional Free Trade Union" group that has recently faced increasing official hostility (founder member, Albina Vakoreva arrived in Vienna last week, after being forced to emigrate). In addition, Senderov, together with fellow mathematician Boris Kanevskii, has for the past four years been monitoring admissions to Moscow University's faculty of mechanics and mathematics.

the lack of auxiliaries is justified on ideological grounds, so that, for example, a scientist who complains that shifting stores to the laboratory is not his job will be castigated as an "elitist". Rather than expand unduly the number of graduates, he said, existing graduates should be better deployed. At present a significant proportion of graduates (estimates range from 12 to 20 per cent) are employed in posts for which a university education is not necessary.

Vera Rich

\section{UK academic posts \\ Muddy waters}

Both the British Home Office and the Committee of Vice-Chancellors of British universities have made moves to try and clear up, once and for all, the confusion that persists over the appointment of overseas candidates to UK academic posts. In a recent letter to the vice-chancellors' committee, the Home Office outlined its interpretation of the immigration laws as applied to university staff. And to help universities abide by that interpretation, the vice-chancellors' committee has appointed a special officer to act as an intermediary in disputed cases.

The confusion seems to have arisen because neither universities nor immigration officials have known how to apply British immigration law to overseas students at British universities who later apply for academic posts. British immigration law is against visitors using their foothold in the country to gain permanent residence. But the Home Office also acknowledges the case for employing foreign academics who could make an outstanding contribution.
Senderov's group claims to have established discrimination against Jews.

In 1979, the team found that of 48 applicants with no Jewish parents or grandparents, who had between them won 26 prizes in the Moscow and AllUnion "Olympiads", 38 were admitted to university on the result of their entrance examinations and a further two on appeal. From a group of 40 having at least one Jewish grandparent, who between them gained 48 prizes in the Olympiads, only four were initially admitted and a further two on appeal. The group's most recent report, signed also by mathematicians Naum Meinan and Grigorii Freiman, shows the same pattern for 1980,41 non-Jewish candidates admitted out of 49 , and two "Jewish" candidates out of fifteen.

The arrest of Senderov on 17 June and of Boris Kanevskii only four days later makes a report on this year's entrance examinations, held in July, very unlikely.

Vera Rich

Hence, determining who should be allowed to stay has often been a lengthy procedure. Universities have taken exception to officials questioning their judgement on who is suitable for a particular job and candidates have been subjected to undue delay before hearing if their applications have been accepted. In some cases, candidates have even been told to go home to their native countries before applying for a work permit.

The Home Office letter signals no change in the law but tries to set out the criteria to be used in deciding whether someone is to get a work permit. There should be evidence, it says, that the person's employment will benefit Britain, either economically or technically, or appreciably enhance Britain's international standing in a particular field of study. The onus is on universities to convince officials that those criteria are met and that no suitable British or EEC national is available for the job.

The vice-chancellors' committee believes that the Home Office letter will help universities by providing guidelines that can be presented before immigration officials.

One further problem for universities, however, could be the Home Office's stipulation that a post must be "justifiable in its own right and not simply in terms of the candidate's abilities"'. In their current financial straits, not many universities are likely to be creating posts for outstanding individuals. But any that have sufficient cash should be able to hook good overseas academics simply by careful argument with the Home Office, according to David Anderson-Evans, senior administration officer at the vice-chancellors' committee.

Judy Redfearn 